\title{
The impact of spring grazing and harvest date on the total forage costs of an integrated grazed and conserved perennial ryegrass sward
}

\section{E Finneran $^{1,2}$, P Crosson ${ }^{1}, \mathrm{M}$ Wallace ${ }^{2}$}

${ }^{1}$ Teagasc, Grange Beef Research Centre, Dunsany, Co Meath, Ireland, ${ }^{2}$ UCD School of Agriculture, Food Science and Veterinary Medicine, Belfield, Dublin 4, Ireland

Email: eoghan.finneran@teagasc.ie

Introduction Feed cost is the greatest variable cost incurred by livestock farms and thus, management of feed cost can impact greatly on the profitability of such farms. Grass, both as a grazed feed or conserved as silage or hay, is the primary feed source on Irish livestock farms. Although these grazed and conserved grass feeds are produced within an integrated grassland management system they are typically costed separately for the purposes of feed cost evaluation (Finneran et al., 2009; Keady et al., 2002). The objective of this study is to model the cost of total annual herbage production from a perennial ryegrass sward which is both grazed (GG) and conserved for grass silage (GS) within an integrated grassland production system.

Materials and methods A static agro-economic simulation model; the Grange Feed Costing Model (GFCM; Finneran et al., 2009) was used to model total annual herbage output and total annual feed cost (TFC) of a sward both grazed and harvested for a single grass silage crop under 20 individual management scenarios. The baseline scenario was a perennial ryegrass sward receiving $200 \mathrm{~kg} \mathrm{~N} \mathrm{ha}^{-1}$ and yielding $12.2 \mathrm{t}$ dry matter (DM) ha ${ }^{-1}$ annually under a rotationally grazed system. Data from six years grass growth plot studies at Teagasc, Grange Beef Research Centre was used to predict weekly GG output. Grazed grass DM yield was reduced appropriately to account for the periods closed for GS production, including the first and second week post harvest. GS production data from Grange (O'Kiely, 2001) was used to predict GS DM yield and dry matter digestibility (DMD). In order to calculate utilised dry matter (UDM) production, a mean utilisation rate of $750 \mathrm{~g} \mathrm{~kg} \mathrm{DM}^{-1}$ was applied for GG across the grazing season, whilst a harvesting and conservation efficiency value of $854 \mathrm{~g} \mathrm{~kg} \mathrm{DM}^{-1}$ was applied for GS. Both GG and GS were fertilised and managed as specified by Finneran et al., (2009). Four spring treatments were evaluated; not spring grazed (NSG) and grazing until $15^{\text {th }}$ March, $31^{\text {st }}$ March and $15^{\text {th }}$ April before closing for grass silage production. Five GS harvest dates at weekly intervals between $29^{\text {th }}$ May and $26^{\text {th }}$ June were modelled. DM yields and DMD at harvest for each of the spring grazed silage crops were calculated using co-efficient for the impact of spring grazing on yield and digestibility derived from O'Riordan et al., (1998) and Humphreys and O'Kiely (2006). Net energy (UFL) was calculated from the DMD value at feed-out.

\section{Results}

Total UDM yield as simulated by the GFCM was greatest for those scenarios where GS comprised the greatest proportion of total DM. UDM yield ranged from $9.2 \mathrm{t} \mathrm{ha}^{-1}$ (closed $15^{\text {th }}$ April, harvest $29^{\text {th }}$ May) to $11.9 \mathrm{t} \mathrm{ha}^{-1}$ (closed $15^{\text {th }} \mathrm{March}$, harvest $26^{\text {th }}$ June). Total UFL output was greatest with a $15^{\text {th }}$ March closing; $12^{\text {th }}$ June harvest. Mean UFL content in the annual UDM ranged from $0.770 \mathrm{~kg} \mathrm{UDM}^{-1}$ (closed $15^{\text {th }}$ March, harvest $26^{\text {th }}$ June) to 0.914 (closed $15^{\text {th }}$ April, harvest $29^{\text {th }}$ May). TFC declined with later GS harvest date for all closing date options on a UDM basis, reflecting the increase in total DM output with increased silage yields (Figure 1). However TFC increases with later harvest on a UFL basis due to the lower mean UFL content of total herbage when a high yield; low DMD GS comprises the majority of the total herbage production. Spring grazing generally decreased TFC on a UFL basis. However TFC was increased

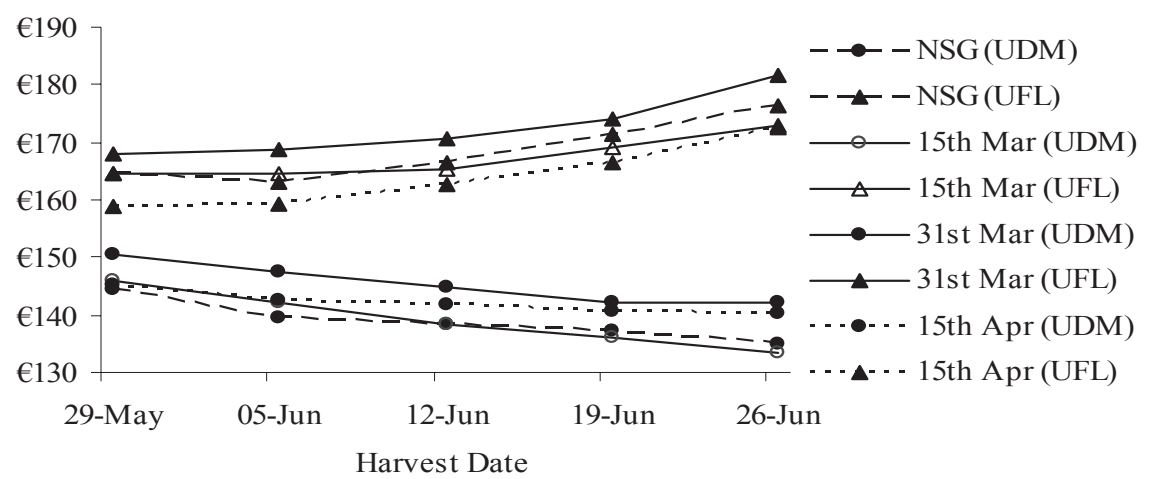
by spring grazing followed by closing on $31^{\text {st }}$ March because the yield of high UFL spring grass grazed was insufficient to offset the subsequent depression in silage yields and hence total annual UFL output.

Conclusions The GFCM analysis indicates that maximisation of mean UFL content in total annual herbage production can result in the lowest TFC for a grazed and harvested perennial ryegrass sward. This is best achieved through efficient grazing of high UFL spring grass and achieving moderate yielding, high UFL silage harvests. TFC can also be reduced on a UDM basis through later GS harvests and higher silage yields with a lower mean UFL content, which may be appropriate depending on the livestock system.

\section{References}

Finneran, E., Crosson, P., Wallace, M., O’Kiely, P., Shalloo, L. and Forristal, D. 2009. Proceedings Agricultural Research Forum, 66.

Humphreys J. and O'Kiely P. 2006. Grass \& Forage Science 61, 77-88.

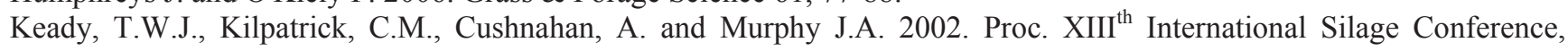
Auchincruive, Scotland, 322-323.

O'Kiely P. 2001. Proceedings Agricultural Research Forum, 51.

O'Riordan E. G., O'Kiely P. and Keane M. G. 1998. Teagasc Beef Production Series 6, 15-18. 